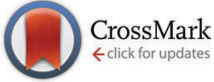

Cite this: Chem. Commun., 2015 51, 15145

Received 19th June 2015, Accepted 21st August 2015

DOI: $10.1039 / \mathrm{c5cc05064b}$

www.rsc.org/chemcomm

\title{
Mechanism of a one-photon two-electron process in photocatalytic hydrogen evolution from ascorbic acid with a cobalt chlorin complex $\dagger$
}

\author{
Shoko Aoi, ${ }^{a}$ Kentaro Mase, ${ }^{a}$ Kei Ohkubo ${ }^{\text {ab }}$ and Shunichi Fukuzumi*abc
}

\begin{abstract}
A one-photon two-electron process was made possible in photocatalytic $\mathrm{H}_{2}$ evolution from ascorbic acid with a cobalt(॥) chlorin complex [Co"(Ch)] via electron transfer from ascorbate to the excited state of $\left[\mathrm{Ru}(\mathrm{bpy})_{3}\right]^{2+}$ followed by electron transfer from $\left[\mathrm{Ru}(\mathrm{bpy})_{3}\right]^{+}$to $\mathrm{Co}^{\prime \prime}(\mathrm{Ch})$ with proton to give the hydride complex, which reacts with proton to produce $\mathrm{H}_{2}$. $\left[\mathrm{Co}{ }^{\prime \prime \prime}(\mathrm{Ch})\right]^{+}$was reduced by ascorbate to reproduce $\mathrm{Co}^{\prime \prime}(\mathrm{Ch})$.
\end{abstract}

Photocatalytic production of hydrogen $\left(\mathrm{H}_{2}\right)$ has attracted increasing attention as a clean energy source because of the ever-increasing demand for energy and climate change on our planet. ${ }^{1}$ A number of highly efficient hydrogen evolving systems have been developed including homogeneous and heterogeneous photocatalytic systems. $^{2-13}$ Two electrons are required to produce $\mathrm{H}_{2}$ from protons, although one photon generates normally only one electron. A mechanism of photocatalytic production of $\mathrm{H}_{2}$ was reported to clarify how photoinduced electron transfer of a photosensitiser (a one-electron process) leads to $\mathrm{H}_{2}$ production (a two-electron process). ${ }^{14-16}$ Disproportionation of one-electron reduced species of metal complexes resulted in formation of the two-electron reduced species from which $\mathrm{H}_{2}$ is formed. ${ }^{17}$ Bimolecular reactions of metal(III)-hydride complexes also generate $\mathrm{H}_{2}$ accompanied by regeneration of metal(II) complexes. ${ }^{18}$ In each case, the maximum quantum yield of $\mathrm{H}_{2}$ production per photon is $50 \%$, because two photons are required to produce two electrons. Thus there has so far been no example for one photon to generate one $\mathrm{H}_{2}$ molecule.

\footnotetext{
${ }^{a}$ Department of Material and Life Science, Graduate School of Engineering, Osaka University, ALCA and SENTAN, Japan Science and Technology Agency (JST), Suita, Osaka 565-0871, Japan.E-mail: fukuzumi@chem.eng.osaka-u.ac.jp; Fax: $+81-6-6879-7370$

${ }^{b}$ Department of Chemistry and Nano Science, Ewha Womans University, Seoul 120-750, Korea

${ }^{c}$ Faculty of Science and Technology, Meijo University, ALCA and SENTAN, Japan Science and Technology Agency (JST), Nagoya, Aichi 468-8502, Japan $\dagger$ Electronic supplementary information (ESI) available: Experimental details and cyclic voltammograms (Fig. S1), time courses of $\mathrm{H}_{2}$ evolution (Fig. S2), emission spectra (Fig. S3 and S5), UV-vis absorption spectra (Fig. S4 and S7) and kinetic data (Fig. S6-S11). See DOI: 10.1039/c5cc05064b
}

We report herein photocatalytic $\mathrm{H}_{2}$ evolution from ascorbic acid $\left(\mathrm{AscH}_{2}\right)$ with a cobalt(II) chlorin complex $\left[\mathrm{Co}^{\mathrm{II}}(\mathrm{Ch})\right]$ (a chemical structure shown in Scheme 1$)^{19}$ in an aqueous acetonitrile solution $\left(\mathrm{H}_{2} \mathrm{O} / \mathrm{MeCN}\right)$, which proceeds via a one-photon two-electron process. The photocatalytic mechanism is clarified by nanosecond laser transient absorption spectra and by examining each step in the catalytic cycle independently.

Visible light irradiation of a deaerated (Ar-saturated) $\mathrm{H}_{2} \mathrm{O}$ / MeCN solution $(1: 1 \mathrm{v} / \mathrm{v})$ of $\left[\mathrm{Ru}(\mathrm{bpy})_{3}\right]^{2+}$ (bpy $=2,2^{\prime}$-bipyridine) containing ascorbic acid $\left(\mathrm{AscH}_{2}\right)$ and ascorbate $\left(\mathrm{AscH}^{-}\right)\left(E_{\mathrm{ox}}=\right.$ $0.43 \mathrm{~V} v$ s. SCE$)$ as an electron donor and $\mathrm{Co}^{\mathrm{II}}(\mathrm{Ch})\left(E_{\mathrm{red}}=-0.96 \mathrm{~V} v\right.$. SCE) (Fig. S1 in the ESI $\dagger$ ) as a catalyst resulted in $\mathrm{H}_{2}$ evolution (Fig. 1, black line). When the ratio of $\mathrm{AscH}^{-}$to $\mathrm{AscH}_{2}$ was changed as fixed total concentrations of $\mathrm{AscH}_{2}$ and $\mathrm{AscH}^{-}\left(\left[\mathrm{AscH}_{2}\right]+\right.$ $\left.\left[\mathrm{AscH}^{-}\right]=1.1 \mathrm{M}\right)$, the largest $\mathrm{H}_{2}$ evolution activity was attained with $\mathrm{AscH}^{-}(0.30 \mathrm{M})$ and $\mathrm{AscH}_{2}(0.80 \mathrm{M})$ (Fig. S2 in ESI $\left.\dagger\right)$. The smaller concentration of $\mathrm{AscH}^{-}$results in less efficient reductive quenching of the $\left[\mathrm{Ru}(\mathrm{bpy})_{3}\right]^{2+*}$ emission $\left({ }^{*}\right.$ denotes the excited state).

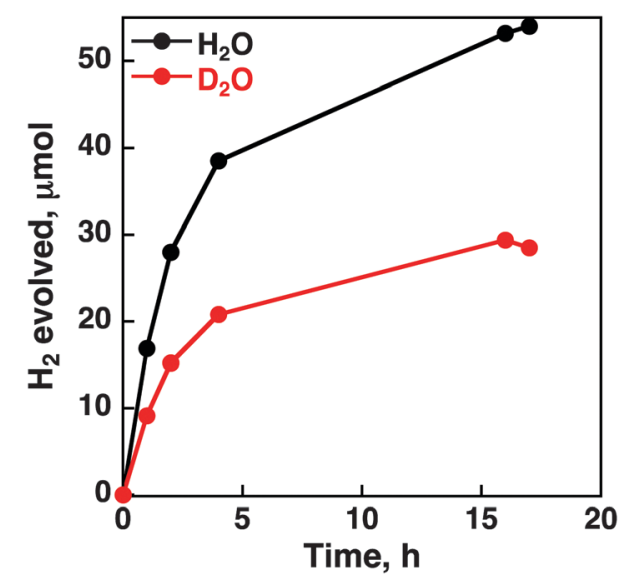

Fig. 1 Time courses of $\mathrm{H}_{2}$ evolution in the photocatalytic reduction of proton in an Ar-saturated $\mathrm{H}_{2} \mathrm{O} / \mathrm{MeCN}$ (black) and $\mathrm{D}_{2} \mathrm{O} / \mathrm{MeCN}$ (red) mixed solution (1:1 v/v) containing [Ru" (bpy) $]_{3}^{2+}(2.0 \mathrm{mM}), \mathrm{AscH}_{2}(0.80 \mathrm{M}), \mathrm{AscHNa}$ $(0.30 \mathrm{M})$ and $\mathrm{CO}^{\prime \prime}(\mathrm{Ch})(25 \mu \mathrm{M})$ under irradiation of visible light $(\lambda>420 \mathrm{~nm})$ at $298 \mathrm{~K}$. 
The quenching efficiency of $\left[\mathrm{Ru}(\mathrm{bpy})_{3}\right]^{2+*}\left(E_{\text {red }}=0.77 \mathrm{~V}\right.$ vs. SCE in $\mathrm{MeCN})^{20}$ by $\mathrm{AscH}^{-}(0.30 \mathrm{M})$ with $\mathrm{AscH}_{2}(0.80 \mathrm{M})$ was determined to be $95 \%$ (Fig. S3 in ESI $\dagger$ ). On the other hand, the smaller concentration of $\mathrm{AscH}_{2}$ may retard $\mathrm{H}_{2}$ production due to decreasing the acidity. When $\mathrm{H}_{2} \mathrm{O}$ was replaced by $\mathrm{D}_{2} \mathrm{O}, \mathrm{D}_{2}$ and $\mathrm{HD}$ were produced without formation of $\mathrm{H}_{2}$. Thus, hydrogen was produced from water and ascorbic acid as electron and proton sources. The observed deuterium kinetic isotope effect (KIE) in Fig. $1\left(k_{\mathrm{H}} / k_{\mathrm{D}}=1.8\right.$ in the initial stage) suggests that the $\mathrm{Co}-\mathrm{H}$ bond cleavage of a cobalt hydride intermediate $\left(\left[\mathrm{Co}^{\mathrm{III}}(\mathrm{H})(\mathrm{Ch})\right]\right)$ by proton may be the ratedetermining step for the photocatalytic $\mathrm{H}_{2}$ evolution (vide infra).

The concentration of $\mathrm{Co}^{\mathrm{II}}(\mathrm{Ch})$ was optimised to be $50 \mu \mathrm{M}$ for the efficient photocatalytic $\mathrm{H}_{2}$ evolution. The absorption of $\left[\mathrm{Ru}(\mathrm{bpy})_{3}\right]^{2+}$ is blocked by the larger concentration of $\mathrm{Co}^{\mathrm{II}}(\mathrm{Ch})$ (Fig. S4 in ESI $\dagger$ ). ${ }^{21}$ The quantum yield of the photocatalytic $\mathrm{H}_{2}$ evolution was determined to be $12 \%$ using a ferric oxalate actinometer (see the Experimental section in ESI $\dagger$ ). This value is similar to the highest value reported for photocatalytic $\mathrm{H}_{2}$ evolution using a cobalt terpyridine complex $(\Phi=0.13) .^{22}$

Nanosecond transient absorption spectra of an $\mathrm{H}_{2} \mathrm{O} / \mathrm{MeCN}$ solution of $\left[\mathrm{Ru}(\mathrm{bpy})_{3}\right]^{2+}$ with $\mathrm{AscH}_{2}$ and $\mathrm{AscH}^{-}$are shown in Fig. 2, where appearance of the absorption band at $500 \mathrm{~nm}$ due to $\left[\mathrm{Ru}(\mathrm{bpy})_{3}\right]^{+}$is observed upon the nanosecond laser excitation. Thus, electron transfer from $\mathrm{AscH}^{-}$to $\left[\mathrm{Ru}(\mathrm{bpy})_{3}\right]^{2+*}$ occurred to produce $\mathrm{AscH}^{\bullet}$ and $\left[\mathrm{Ru}(\mathrm{bpy})_{3}\right]^{+}$. The rate constant of electron transfer from $\mathrm{AscH}^{-}$to $\left[\mathrm{Ru}(\mathrm{bpy})_{3}\right]^{2+*}\left(k_{\mathrm{et}}\right)$ was determined to be $8.0 \times 10^{8} \mathrm{M}^{-1} \mathrm{~s}^{-1}$ from a slope of Stern-Volmer plot $\left(K_{\mathrm{SV}}=3.5 \times 10^{2} \mathrm{M}^{-1}\right)$ and the lifetime of $\left[\mathrm{Ru}(\mathrm{bpy})_{3}\right]^{2+*}(0.44 \mu \mathrm{s}$ in water/MeCN $1: 1 \mathrm{v} / \mathrm{v})$ (Fig. S5 in $\mathrm{ESI} \dagger)^{23}$ The decay rate of absorbance at $500 \mathrm{~nm}$ due to $\left[\mathrm{Ru}(\mathrm{bpy})_{3}\right]^{+}$ obeyed the second-order kinetics of bimolecular back electron transfer from $\left[\mathrm{Ru}(\mathrm{bpy})_{3}\right]^{+}$to $\mathrm{AscH}^{\bullet}$. In the presence of $\mathrm{Co}^{\mathrm{II}}(\mathrm{Ch})$, the decay of absorbance became much faster because of electron transfer from $\left[\mathrm{Ru}(\mathrm{bpy})_{3}\right]^{+}$to $\mathrm{Co}^{\mathrm{II}}(\mathrm{Ch})$ as shown in Fig. 2b. The decay rate constant linearly increased with increasing the concentration of $\left[\mathrm{Co}^{\mathrm{II}}(\mathrm{Ch})\right]$ (Fig. S6 in ESI $\left.\dagger\right)$. The rate constant of electron transfer from $\left[\mathrm{Ru}(\mathrm{bpy})_{3}\right]^{+}$to $\mathrm{Co}^{\mathrm{II}}(\mathrm{Ch})$ was determined to be $2.5 \times 10^{9} \mathrm{M}^{-1} \mathrm{~s}^{-1}$ from the slope of dependence of the first-order decay rate constant on concentration of $\mathrm{Co}^{\mathrm{II}}(\mathrm{Ch})$ (Fig. S6b in $\mathrm{ESI} \dagger$ ).
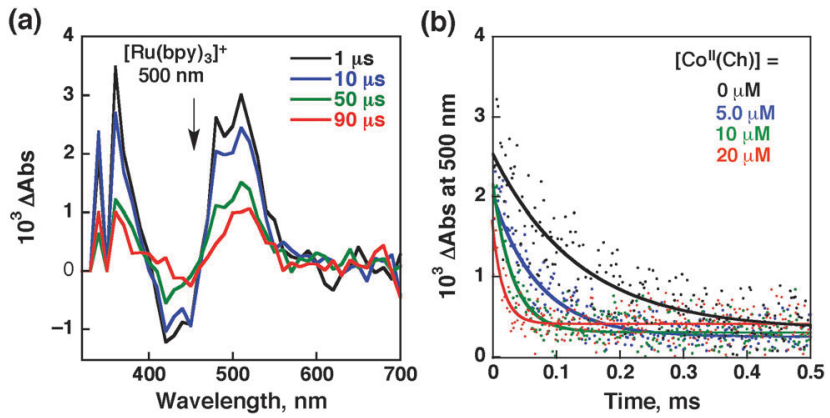

Fig. 2 (a) Transient absorption spectra after laser excitation ( $\lambda=450 \mathrm{~nm}$ ) of $\left[\mathrm{Ru}^{\prime \prime}(\mathrm{bpy})_{3}\right]^{2+}(80 \mu \mathrm{M})$ in the presence of $\mathrm{AscH}_{2}(0.80 \mathrm{M})$ and $\mathrm{AscHNa}$ $(0.30 \mathrm{M})$ in a deaerated $\mathrm{H}_{2} \mathrm{O} / \mathrm{MeCN}$ mixed solution $(1: 1 \mathrm{v} / \mathrm{v})$ at $298 \mathrm{~K}$. (b) Time profiles of absorbance at $500 \mathrm{~nm}$ due to decay of $\left[\mathrm{Ru}(\mathrm{bpy})_{3}\right]^{+}$in the presence of various concentrations of $\mathrm{CO}^{\prime \prime}(\mathrm{Ch})(0-20 \mu \mathrm{M})$ in deaerated $\mathrm{H}_{2} \mathrm{O} / \mathrm{MeCN}$ mixed solutions $(1: 1 \mathrm{v} / \mathrm{v})$ containing $\left[\mathrm{Ru}^{\mathrm{Il}}(\mathrm{bpy})_{3}\right]^{2+}(80 \mu \mathrm{M})$, $\mathrm{AsCH}_{2}(0.80 \mathrm{M})$, AscHNa (0.30 M).
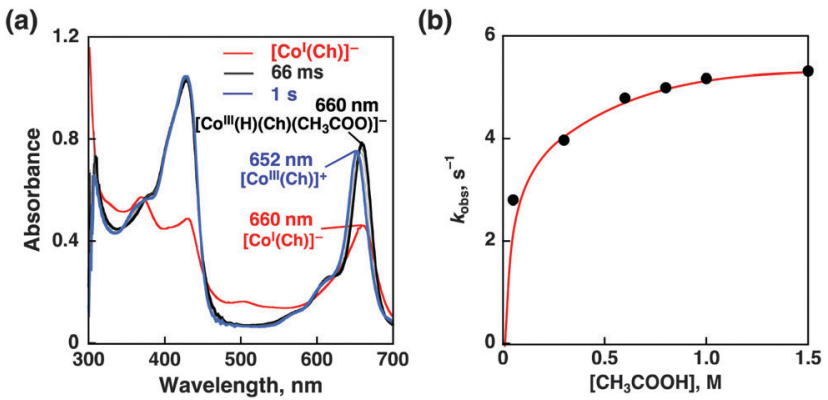

Fig. 3 (a) UV-vis absorption spectral changes of $\left[\mathrm{Co}^{\prime}(\mathrm{Ch})\right]^{-}(30 \mu \mathrm{M})$ upon addition of $\mathrm{CH}_{3} \mathrm{COOH}(0.30 \mathrm{M})$ in dearated $\mathrm{MeCN}$ at $298 \mathrm{~K}$. The black and blue lines show the spectra taken at $66 \mathrm{~ms}$ and $1 \mathrm{~s}$ after mixing, respectively. The red line shows UV-vis absorption spectrum of $\left[\mathrm{Co}^{\prime}(\mathrm{Ch})\right]^{-}(15 \mu \mathrm{M})$ formed by the electron-transfer reduction of Co" $(\mathrm{Ch})(15 \mu \mathrm{M})$ with $\mathrm{CoCp}_{2}$ * $(300 \mu \mathrm{M})$ in dearated $\mathrm{MeCN}$ at $298 \mathrm{~K}$. (b) Plot of $k_{\mathrm{obs}}$ for the rate of formation of $[\mathrm{Co} \text { "I' }(\mathrm{Ch})]^{+}$vs. $\left[\mathrm{CH}_{3} \mathrm{COOH}\right]$.

To examine the reaction of $\left[\mathrm{Co}^{\mathrm{I}}(\mathrm{Ch})\right]^{-}$that is produced by electron transfer from $\left[\mathrm{Ru}(\mathrm{bpy})_{3}\right]^{+}$to $\mathrm{Co}^{\mathrm{II}}(\mathrm{Ch}),\left[\mathrm{Co}^{\mathrm{I}}(\mathrm{Ch})\right]^{-}$was prepared by the one-electron reduction of $\mathrm{Co}^{\mathrm{II}}(\mathrm{Ch})$ by decamethylcobaltocene $\left[\mathrm{Co}\left(\mathrm{Cp}^{*}\right)_{2}\right]$ in $\mathrm{MeCN}$ (Fig. S7 in ESI $\dagger$ ). The UV-vis absorption band of $\left[\mathrm{Co}^{\mathrm{I}}(\mathrm{Ch})\right]^{-}$(red line in Fig. $3 \mathrm{a} ; \lambda_{\max }=$ $510 \mathrm{~nm}$ ) decreased with increasing absorption band at $660 \mathrm{~nm}$ (black line) at $66 \mathrm{~ms}$ after addition of acetic acid $\left(\mathrm{CH}_{3} \mathrm{COOH}\right)$ $(0.30 \mathrm{M})$. Then, this absorption band was finally blue shifted to $\lambda_{\text {max }}=652 \mathrm{~nm}$, which is due to $\left[\mathrm{Co}^{\mathrm{III}}(\mathrm{Ch})\right]^{+} \cdot{ }^{24,25}$ Thus, $\left[\mathrm{Co}^{\mathrm{I}}(\mathrm{Ch})\right]^{-}$ may react with $\mathrm{CH}_{3} \mathrm{COOH}$ to form the hydride complex $\left(\left[\mathrm{Co}^{\mathrm{III}}(\mathrm{H})(\mathrm{Ch})\left(\mathrm{CH}_{3} \mathrm{COO}\right)\right]^{-}: \lambda_{\max }=660 \mathrm{~nm}\right)$, from which $\mathrm{H}_{2}$ was evolved by the reaction with $\mathrm{CH}_{3} \mathrm{COOH}$ to produce $\left[\mathrm{Co}^{\mathrm{III}}(\mathrm{Ch})\right]^{+}$. The reaction of $\left[\mathrm{Co}^{\mathrm{I}}(\mathrm{Ch})\right]^{-}$with $\mathrm{CH}_{3} \mathrm{COOH}$ was monitored by the absorption change at $652 \mathrm{~nm}$ due to $\left[\mathrm{Co}^{\mathrm{III}}(\mathrm{Ch})\right]^{+}$as shown in Fig. 3, where the rate of the formation of $\left[\mathrm{Co}^{\mathrm{III}}(\mathrm{Ch})\right]^{+}$obeyed first-order kinetics (Fig. S8 in ESI $\dagger$ ). The first-order rate constant increased with increasing concentration of $\mathrm{CH}_{3} \mathrm{COOH}$ to approach a constant value (Fig. 3b). Such a saturation behaviour indicates that $\mathrm{CH}_{3} \mathrm{COOH}$ is not involved in the rate-determining step and that the reaction of $\left[\mathrm{Co}^{\mathrm{I}}(\mathrm{Ch})\right]^{-}$with $\mathrm{CH}_{3} \mathrm{COOH}$ proceeds via formation of the hydride complex $\left(\left[\mathrm{Co}^{\mathrm{III}}(\mathrm{H})(\mathrm{Ch})\left(\mathrm{CH}_{3} \mathrm{COO}\right)\right]^{-}\right)$, followed by the rate-determining heterolytic cleavage of the $\mathrm{Co}^{\mathrm{III}}-\mathrm{H}$ bond. The subsequent reaction of the released hydride ion with $\mathrm{CH}_{3} \mathrm{COOH}$ to produce $\mathrm{H}_{2}$ and $\left[\mathrm{Co}^{\mathrm{III}}(\mathrm{Ch})\right]^{+}$may be fast as compared with the back reaction of the $\mathrm{Co}^{\mathrm{III}}-\mathrm{H}$ bond cleavage (Scheme 1). The kinetic equation for the formation of $\left[\mathrm{Co}^{\mathrm{III}}(\mathrm{Ch})\right]^{+}$ is given by eqn (1),
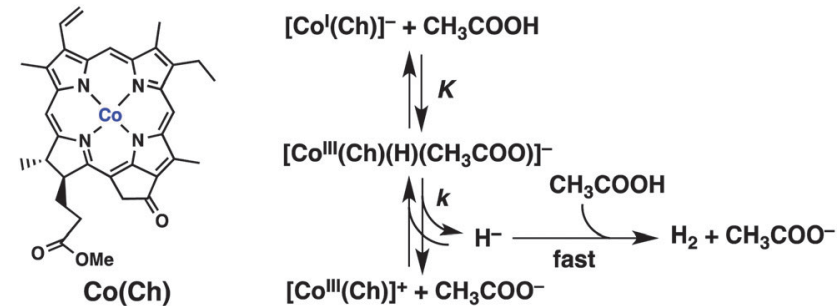

Scheme 1 Mechanism of hydrogen formation by the reaction of $\left[\mathrm{Co}^{\prime}(\mathrm{Ch})\right]^{-}$ with $\mathrm{CH}_{3} \mathrm{COOH}$. 


$$
\mathrm{d}\left[\left[\mathrm{Co}^{\mathrm{III}}(\mathrm{Ch})\right]^{+}\right] / \mathrm{d} t=k\left[\left[\mathrm{Co}^{\mathrm{III}}(\mathrm{H})(\mathrm{Ch})\left(\mathrm{CH}_{3} \mathrm{COO}\right)\right]^{-}\right]
$$

where $k$ is the rate constant of the hydrogen evolution. From the equilibrium constant $(K)$, the concentration of a complex between $\left[\mathrm{Co}^{\mathrm{I}}(\mathrm{Ch})\right]^{-}$and $\mathrm{CH}_{3} \mathrm{COOH}$ is given by eqn (2), where

$$
\begin{gathered}
{\left[\left[\mathrm{Co}^{\mathrm{III}}(\mathrm{H})(\mathrm{Ch})\left(\mathrm{CH}_{3} \mathrm{COO}\right)\right]^{-}\right]=K\left[\mathrm{CH}_{3} \mathrm{COOH}\right]\left(\left[\left[\mathrm{Co}^{\mathrm{I}}(\mathrm{Ch})\right]^{-}\right]_{0}\right.} \\
\left.-\left[\left[\mathrm{Co}^{\mathrm{III}}(\mathrm{Ch})\right]^{+}\right]\right) /\left(1+K\left[\mathrm{CH}_{3} \mathrm{COOH}\right]\right)
\end{gathered}
$$

$\left[\left[\mathrm{Co}^{\mathrm{I}}(\mathrm{Ch})\right]^{-}\right]_{0}$ is the initial concentration. Eqn (1) is rewritten by eqn (3).

$$
\begin{gathered}
\mathrm{d}\left[\left[\mathrm{Co}^{\mathrm{III}}(\mathrm{Ch})\right]^{+}\right] / \mathrm{d} t=k K\left[\mathrm{CH}_{3} \mathrm{COOH}\right]\left(\left[\left[\mathrm{Co}^{\mathrm{I}}(\mathrm{Ch})\right]^{-}\right]_{0}\right. \\
\left.-\left[\left[\mathrm{Co}^{\mathrm{III}}(\mathrm{Ch})\right]^{+}\right]\right) /\left(1+K\left[\mathrm{CH}_{3} \mathrm{COOH}\right]\right)
\end{gathered}
$$

Under the conditions, the concentration of $\mathrm{CH}_{3} \mathrm{COOH}$ is much higher than that of $\left[\mathrm{Co}^{\mathrm{I}}(\mathrm{Ch})\right]^{-}$, the $k_{\text {obs }}$ value is given by eqn (4). To determine the $k$ value, eqn (4) is rewritten by eqn (5), which predicts

$$
\begin{gathered}
k_{\mathrm{obs}}=k K\left[\mathrm{CH}_{3} \mathrm{COOH}\right] /\left(1+K\left[\mathrm{CH}_{3} \mathrm{COOH}\right]\right) \\
k_{\mathrm{obs}}{ }^{-1}=1 / k K \cdot\left[\mathrm{CH}_{3} \mathrm{COOH}\right]^{-1}+1 / k
\end{gathered}
$$

a linear correlation between $k_{\text {obs }}{ }^{-1}$ and $\left[\mathrm{CH}_{3} \mathrm{COOH}\right]^{-1}$ (Fig. S9 in ESI $\dagger$ ). The $k$ and $K$ values were determined from the intercept and slope of the linear plot of $k_{\mathrm{obs}}{ }^{-1} v s .\left[\mathrm{CH}_{3} \mathrm{COOH}\right]^{-1}$ to be $5.9 \mathrm{~s}^{-1}$ and $7.1 \mathrm{M}^{-1}$.

When $\mathrm{CH}_{3} \mathrm{COOH}$ was replaced by $\mathrm{CH}_{3} \mathrm{COOD}$, the deuterium kinetic isotope effect (KIE) was observed (Fig. S10 in ESI $\dagger$ ), ${ }^{26}$ indicating that the cleavage of the $\mathrm{Co}-\mathrm{H}$ bond of $\left[\mathrm{Co}^{\mathrm{III}}(\mathrm{H})-\right.$ (Ch) $\left.\left(\mathrm{CH}_{3} \mathrm{COO}\right)\right]^{-}$or $\mathrm{O}-\mathrm{H}$ bond of $\mathrm{CH}_{3} \mathrm{COOH}$ is involved in the ratedetermining step of the reaction of $\left[\mathrm{Co}^{\mathrm{I}}(\mathrm{Ch})\right]^{-}$with $\mathrm{CH}_{3} \mathrm{COOH}$. Because $\mathrm{CH}_{3} \mathrm{COOH}$ is not involved in the rate-determining step (vide infra), the cleavage of the $\mathrm{Co}-\mathrm{H}$ bond of $\left[\mathrm{Co}^{\mathrm{III}}(\mathrm{H})(\mathrm{Ch})-\right.$ $\left.\left(\mathrm{CH}_{3} \mathrm{COO}\right)\right]^{-}$is the rate-determining step of the reaction of $[\mathrm{Co}(\mathrm{Ch})]^{-}$with $\mathrm{CH}_{3} \mathrm{COOH}$. The $\mathrm{KIE}$ value was 1.7 which is virtually the same as observed for the photocatalytic $\mathrm{H}_{2}$ evolution ( $\mathrm{KIE}=1.8$, Fig. 1), indicating that the heterolytic $\mathrm{Co}-\mathrm{H}$ bond cleavage of $\left[\mathrm{Co}^{\mathrm{III}}(\mathrm{H})(\mathrm{Ch})\left(\mathrm{CH}_{3} \mathrm{COO}\right)\right]^{-}$is also the rate-determining step in the photocatalytic $\mathrm{H}_{2}$ evolution.
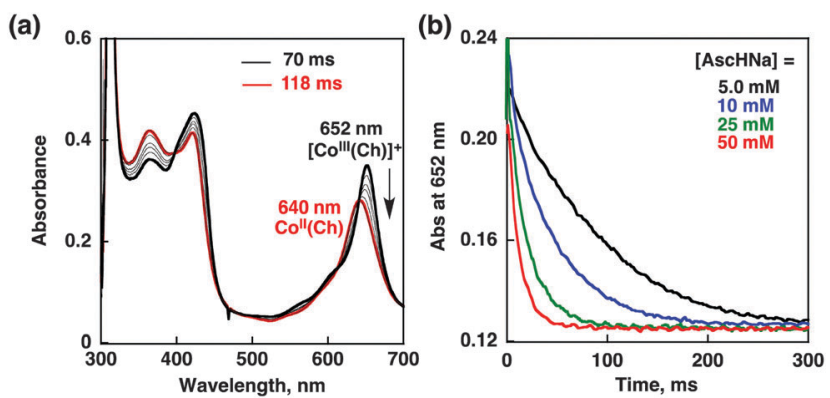

Fig. 4 (a) UV-vis absorption spectral changes in the electron-transfer reduction of [Co"l'(Ch) ${ }^{+}(15 \mu \mathrm{M})$ with AscHNa $(50 \mathrm{mM})$ in air-saturated $\mathrm{H}_{2} \mathrm{O} / \mathrm{MeCN}$ mixed solutions $(1: 1 \mathrm{v} / \mathrm{v})$ at $298 \mathrm{~K}$ taken at $70 \mathrm{~ms}$ and $118 \mathrm{~ms}$ after mixing. (b) Decay time profiles of absorbance at $652 \mathrm{~nm}$ due to $\left[\mathrm{CO}^{\prime \prime \prime}(\mathrm{Ch})\right]^{+}$in the presence of various concentrations of AscHNa in airsaturated $\mathrm{H}_{2} \mathrm{O} / \mathrm{MeCN}$ mixed solutions $(1: 1 \mathrm{v} / \mathrm{v})$ at $298 \mathrm{~K}$.

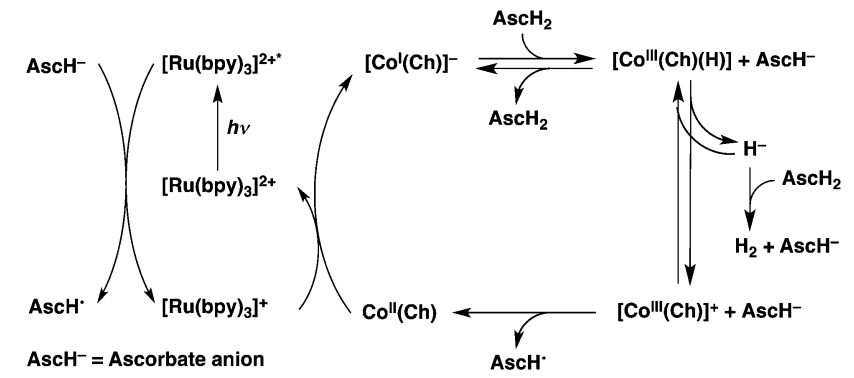

Scheme 2 Mechanism of photocatalytic hydrogen evolution from $\mathrm{AscH}^{-}$ and $\mathrm{AsCH}_{2}$ with $\left[\mathrm{Ru}(\mathrm{bpy})_{3}\right]^{2+}$ and $\mathrm{CO}^{\prime \prime}(\mathrm{Ch})$.

$\left[\mathrm{Co}^{\mathrm{III}}(\mathrm{Ch})\right]^{+}$produced by the reaction of $\left[\mathrm{Co}^{\mathrm{III}}(\mathrm{H})(\mathrm{Ch})-\right.$ $\left.\left(\mathrm{CH}_{3} \mathrm{COO}\right)\right]^{-}$with $\mathrm{CH}_{3} \mathrm{COOH}$ is reduced by $\mathrm{AscH}^{-}$to form $\mathrm{Co}(\mathrm{Ch})$ as shown by stopped-flow measurements in Fig. $4 .{ }^{27}$ The rate constant of electron transfer from $\mathrm{AscH}^{-}$to $\left[\mathrm{Co}^{\mathrm{III}}(\mathrm{Ch})\right]^{+}$that was prepared by the one-electron oxidation of $\mathrm{Co}^{\mathrm{II}}(\mathrm{Ch})$ with $\left(p-\mathrm{BrC}_{6} \mathrm{H}_{4}\right)_{3} \mathrm{~N}^{\bullet+} \mathrm{SbCl}_{6}{ }^{-}$in $\mathrm{H}_{2} \mathrm{O} / \mathrm{MeCN}$ was determined to be $1.5 \times$ $10^{3} \mathrm{M}^{-1} \mathrm{~s}^{-1}$ from the linear dependence of the first-order rate constant on concentration of $\mathrm{AscH}^{-}$(Fig. S11 in ESI†).

The photocatalytic cycle is summarized in Scheme 2. Photoexcitation of $\left[\mathrm{Ru}(\mathrm{bpy})_{3}\right]^{2+}$ resulted in electron transfer from $\mathrm{AscH}^{-}$to $\left[\mathrm{Ru}(\mathrm{bpy})_{3}\right]^{2+*}$ to produce $\left[\mathrm{Ru}(\mathrm{bpy})_{3}\right]^{+}$, followed by electron transfer from $\left[\mathrm{Ru}(\mathrm{bpy})_{3}\right]^{+}$to $\mathrm{Co}^{\mathrm{II}}(\mathrm{Ch})$ to produce $\left[\mathrm{Co}^{\mathrm{I}}(\mathrm{Ch})\right]^{-}$, which reacts with $\mathrm{AscH}_{2}$ to produce $\left[\mathrm{Co}^{\mathrm{III}}(\mathrm{H})(\mathrm{Ch})(\mathrm{AscH})\right]^{-}$. Hydrogen is generated by the reaction of $\left[\mathrm{Co}^{\mathrm{II}}(\mathrm{H})(\mathrm{Ch})(\mathrm{AscH})\right]^{-}$with $\mathrm{AscH}_{2}$ via the $\mathrm{Co}-\mathrm{H}$ bond heterolysis to produce $\left[\mathrm{Co}^{\mathrm{III}}(\mathrm{Ch})\right]^{+28,29}$ which is reduced by $\mathrm{AscH}^{-}$to regenerate $\mathrm{Co}^{\mathrm{II}}(\mathrm{Ch})$. In such a case, a one-photon two-electron process is made possible, because one photon is required to produce $\left[\mathrm{Co}^{\mathrm{I}}(\mathrm{Ch})\right]^{-}$for $\mathrm{H}_{2}$ evolution and another electron is provided thermally by $\mathrm{AscH}^{-}$.

In conclusion, $\mathrm{Co}^{\mathrm{II}}(\mathrm{Ch})$ acts as an efficient catalyst for photocatalytic $\mathrm{H}_{2}$ evolution from ascorbic acid with $\left[\mathrm{Ru}(\mathrm{bpy})_{3}\right]^{2+}$ as a photocatalyst to attain the high quantum yield via a one-photon two-electron process in which the second electron is provided thermally from ascorbic acid.

This work was supported by Grants-in-Aid (no. 26620154 and 26288037 to K.O.) and JSPS fellowship (No. 25-727 to K.M.) from the Ministry of Education, Culture, Sports, Science and Technology (MEXT); ALCA and SENTAN projects from JST, Japan (to S.F.).

\section{Notes and references}

1 R. A. Kerr and R. F. Service, Science, 2005, 309, 101.

2 X. Song, H. Wen, C. Ma, H. Chen and C. Chen, New J. Chem., 2015, 39, 1734.

3 K. Kawano, K. Yamauchi and K. Sakai, Chem. Commun., 2014, 50, 9872.

4 X. Wang, S. Goeb, Z. Ji, N. A. Pogulaichenko and F. N. Castellano, Inorg. Chem., 2011, 50, 705.

5 L.-Z. Fu, L.-L. Zhou, L.-Z. Tang, Y.-X. Xhang and S.-Z. Zhan, J. Power Sources, 2015, 280, 453.

6 S. Fukuzumi, Curr. Opin. Chem. Biol., 2015, 25, 18.

7 D. Basu, S. Mazumder, X. Shi, H. Baydoun, J. Niklas, O. Poluektov, H. B. Schlegel and C. N. Verani, Angew. Chem., Int. Ed., 2015, 54, 2105.

8 A. Call, Z. Codola, F. Acuna-Pares and J. Lloret-Fillol, Chem. - Eur. J., 2014, 20, 6171.

9 H. Lv, W. Guo, K. Wu, Z. Chen, J. Bacsa, D. G. Musaev, Y. V. Geletii, S. M. Lauinger, T. Lian and C. L. Hill, J. Am. Chem. Soc., 2014, 136, 14015. 
10 L. Chen, G. Chen, C.-F. Leung, S.-M. Yiu, C.-C. Ko, E. AnxolabéhèreMallart, M. Robert and T.-C. Lau, ACS Catal., 2015, 5, 356.

11 A. Zarkadoulas, E. Koutsouri, C. Kefalidi and C. A. Mitsopoulou, Coord. Chem. Rev., 2014, 11, 6.

12 K. Maeda, M. Eguchi and T. Oshima, Angew. Chem., Int. Ed., 2014, 53, 13164.

13 J. Zhao, Y. Ding, J. Wei, X. Du, Y. Yu and R. Han, Int. J. Hydrogen Energy, 2014, 39, 18908.

14 E. Deponti, A. Luisa, M. Natali, E. lengo and F. Scandola, Dalton Trans., 2014, 43, 16345.

15 H. Ozawa and K. Sakai, Chem. Commun., 2011, 47, 2227.

16 A. Rodenberg, M. Orazietti, B. Probst, C. Bachmann, R. Alberto, K. K. Baldridge and P. Hamm, Inorg. Chem., 2015, 54, 646.

17 S. Fukuzumi, T. Kobayashi and T. Suenobu, Angew. Chem., Int. Ed., 2011, 50, 728.

18 J. L. Dempsey, B. S. Brunschwig, J. R. Winkler and H. B. Gray, Acc. Chem. Res., 2009, 42, 1995.

19 K. Mase, K. Ohkubo and S. Fukuzumi, J. Am. Chem. Soc., 2013, 135, 2800. 20 J. Yuasa and S. Fukuzumi, J. Am. Chem. Soc., 2006, 128, 14281.

21 The photocatalytic $\mathrm{H}_{2}$ evolution in our optimized conditions, the absorption at $\lambda=450 \mathrm{~nm}$ of $\left[\mathrm{Ru}(\mathrm{bpy})_{3}\right]^{2+}\left(2.0 \mathrm{mM}, \varepsilon_{450 \mathrm{~nm}}=1.4 \times\right.$ $\left.10^{4} \mathrm{M}^{-1} \mathrm{~cm}^{-1}\right)$ is not significantly blocked by that of $\mathrm{Co}(\mathrm{Ch})\left(\mathrm{Abs}_{450 \mathrm{~nm}}=\right.$ $0.38 ; \varepsilon_{450 \mathrm{~nm}}=1.8 \times 10^{4} \mathrm{M}^{-1} \mathrm{~cm}^{-1}$ ) under this experimental conditions.
22 C. V. Krishnan and N. Sutin, J. Am. Chem. Soc., 1981, 103, 2141.

23 The emission lifetime of $\left[\mathrm{Ru}(\mathrm{bpy})_{3}\right]^{2+*}$ in water at $298 \mathrm{~K}$ was reported to be $0.58 \mu \mathrm{s}$; see: J. V. Houten and R. J. Watts, J. Am. Chem. Soc., 1976, 98, 4853.

24 The spectrum of $\left[\mathrm{Co}^{\mathrm{III}}(\mathrm{Ch})\right]^{+}$obtained by the reaction $\left[\mathrm{Co}^{\mathrm{I}}(\mathrm{Ch})\right]^{-}$ with $\mathrm{CH}_{3} \mathrm{COOH}$ was identical to that of $\left[\mathrm{Co}^{\mathrm{III}}(\mathrm{Ch})\right]^{+}$prepared by the electron-transfer oxidation of $\mathrm{Co}^{\mathrm{II}}(\mathrm{Ch})$ by a one-electron oxidizing reagent of $\left(p-\mathrm{BrC}_{6} \mathrm{H}_{4}\right)_{3} \mathrm{~N}^{\bullet+} \mathrm{SbCl}_{6}{ }^{-}\left(E_{\text {red }}=1.05 \mathrm{~V}\right.$ vs. SCE $) .{ }^{19}$.

$25\left[\mathrm{Co}^{\mathrm{III}}(\mathrm{Ch})\right]^{+}$or $\mathrm{Co}^{\mathrm{II}}(\mathrm{H})(\mathrm{Ch})$ species is not re-reduced by large excess of $\mathrm{Co}\left(\mathrm{Cp}^{*}\right)_{2}$, under the present reaction conditions because $\mathrm{Co}^{\mathrm{II}}(\mathrm{Ch})$ with 20 molar equiv. of $\mathrm{Co}\left(\mathrm{Cp}^{*}\right)_{2}$ is necessary to quantitatively produce $\left[\mathrm{Co}^{\mathrm{I}}(\mathrm{Ch})\right]^{-}$as shown in ESI, $\uparrow$ Fig. S7. $\mathrm{Co}\left(\mathrm{Cp}^{*}\right)_{2}\left(E_{1 / 2}^{+/ 0}=\right.$ $-1.47 \mathrm{~V}$ vs. SCE) is unstable even in carefully degassed and dehydrated MeCN.

26 The KIE value was determined from the $k_{\text {obs }}$ values at $\left[\mathrm{CH}_{3} \mathrm{COOH}\right]=$ $\left[\mathrm{CH}_{3} \mathrm{COOD}\right]=1.0 \mathrm{M}$.

27 Neither oxidation of $\left[\mathrm{Co}^{\mathrm{III}}(\mathrm{Ch})\right]^{+}$nor $\mathrm{O}_{2}$ reduction was observed under the basic reaction conditions.

28 S. Mandal, S. Shikano, Y. Yamada, Y.-M. Lee, W. Nam, A. Llobet and S. Fukuzumi, J. Am. Chem. Soc., 2013, 135, 15294.

29 No Co(II)-H complex is involved in the heterolysis of the Co-H bond as reported in ref. 28. 